\title{
Physico-Chemical Properties of the Pyrolytic Residue Obtained by Different Treatment Conditions of Meat and Bone Meal
}

\author{
Marija Zupančič and Nataša Čelan Korošin* \\ Faculty of Chemistry and Chemical Technology, University of Ljubljana, Večna pot 113, 1000 Ljubljana, Slovenia \\ *Corresponding author: E-mail: Natasa.Celan@fkkt.uni-lj.si \\ Phone: +38614798524
}

Received: 09-25-2020

\begin{abstract}
The depletion of phosphate rock reserves has led to the search for new, alternative and environmentally friendly products and processes. One of the safe and environmentally friendly sources of phosphate is animal bone char (ABC), the residue from the pyrolysis of meat and bone meal (MBM), a slaughterhouse waste material. The presented study investigated the physico-chemical properties of the residues $(\mathrm{ABC})$ obtained from the pyrolysis of MBM under different treatment conditions. Two different end temperatures $\left(600^{\circ} \mathrm{C}\right.$ and $\left.1000^{\circ} \mathrm{C}\right)$ and five different heating rates $\left(5^{\circ} \mathrm{C} \mathrm{min}^{-1}, 10^{\circ} \mathrm{C} \mathrm{min}^{-1}\right.$, $20^{\circ} \mathrm{C} \mathrm{min}-1,50^{\circ} \mathrm{C} \mathrm{min}^{-1}$ and $100^{\circ} \mathrm{C} \mathrm{min}^{-1}$ ) were used. The $\mathrm{ABC}$ samples obtained were characterised by X-ray powder diffraction, IR spectroscopy, elemental CHNS analysis and SEM/EDS analysis. The results showed the strong influence of both the pyrolysis end temperature and the heating rate on the morphology and chemical composition of the final products.
\end{abstract}

Keywords: Bone char, meat and bone meal, natural hydroxyapatite, phosphate sources, pyrolysis, thermogravimetry

\section{Introduction}

One of the main problems in many modern agricultural systems is the lack of sustainable development. The unauthorized use of chemicals, e.g. in phosphate fertilizers, has led to the eutrophication of waters, to the harming of many beneficial soil organisms and, as a result, to a negative impact on the level of biodiversity. The careful use of phosphate fertilizers leads to the better management of existing phosphorus sources and its continued circulation in nature. The existing fertilizer industry is based exclusively on non-renewable resources, i.e., a high grade phosphate ores that, according to one report, could be exhausted in as little as $60-80$ years. ${ }^{1}$

Meat and bone meal (MBM) is a by-product of the rendering industry. Due to the medium-high heating value of MBM, the pyrolysis, gasification, combustion and co-combustion processes were studied as an environmentally friendly alternative to landfilling. ${ }^{2-12}$ During the controlled pyrolysis process raw MBM decompose into number of useful products i.e. gas, tar, oil and char, that make it more attractive than other thermal processes. The speed and the extent of the decomposition depend on process parameters such as the temperature in the reactor, the heating rate of the biomass, the pressure and the composition of the raw material. ${ }^{13}$

The solid residue of pyrolysed meat and bone meal, animal bone char $(\mathrm{ABC})$, is a granular material that, in contrast to the biochar from plant biomass, contains a much smaller percentage of organic carbon (about $10 \%$ ). For this reason, it cannot be categorized as biochar, but as pyrogenic carbonated material. ${ }^{14,15}$ The carbon, which remains trapped in the structure after pyrolytic decomposition of $M B M$, increases the specific surface of $A B C$ compared to crystalline hydroxyapatite (HA). ${ }^{16}$ Due to its high phosphate content, $\mathrm{ABC}$ can be used as a source for P-fertilizer production or as a stabilizing agent in the remediation of potentially toxic elements (PTE) contaminated sites. ${ }^{17-20}$

A few studies investigated the influence of treatment conditions of pyrolysis of bone meal on the properties of the bone char obtained. ${ }^{21-23}$ In contrast to the pyrolysis of bone meal, the pyrolysis of MBM poses a much greater challenge. Despite many studies that have investigated 
the pyrolysis process of MBM, data on the influence of experimental conditions on the properties of MBM pyrolysis products are seldom available. In order to improve the knowledge in this field, the aim of this work was to evaluate the influence of the MBM pyrolysis end temperature and the different heating rates on physico-chemical properties and the composition of the solid residue, $\mathrm{ABC}$, focusing on a detailed analysis of the morphology and composition of the $\mathrm{ABC}$ samples. The pyrolysis of the MBM sample was performed at five different heating rates (from $5{ }^{\circ} \mathrm{C} \mathrm{min}{ }^{-1}$ to $100^{\circ} \mathrm{C} \mathrm{min}{ }^{-1}$ ). Due to the large amount of organic matter in MBM the lowest pyrolysis end temperature examined was chosen at $600{ }^{\circ} \mathrm{C}$. The characteristics of these residues were compared with residues obtained at $\mathrm{MBM}$ pyrolysis end temperature of $1000^{\circ} \mathrm{C}$, where the release of $\mathrm{CO}_{2}$ from carbonates is expected to be completed. ${ }^{24}$

\section{Experimental}

MBM sample category 3 (low-risk material from the production of goods intended for human consumption using slaughtered animals not affected by any sign of diseases that are transmissible to humans or other animals) was obtained from a local slaughterhouse, where non-harmful animal remains are ground up, heated with steam for sterilization and with the animal fats squeezed out to obtain meat and bone meal. The sample was first dried for 24 hours at $100{ }^{\circ} \mathrm{C}$, ground with a planetary mill (Retsch PM100, Germany) into fine powder and sieved through a $0.250 \mathrm{~mm}$ test sieve (ISO 3310-1, Retsch, Germany).

The MBM was pyrolysed in a Mettler Toledo $(\mathrm{CH})$ TGA/SDTA 851e LF1100 system for Thermal Analysis. Subsamples of $20 \mathrm{mg}$ were inserted into the alumina crucible $(150 \mu \mathrm{L})$ and heat treated in an argon atmosphere

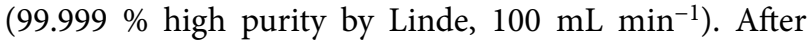
an initial $30 \mathrm{~min}$ of isothermal conditioning at $25^{\circ} \mathrm{C}$ the samples were dynamically heated up to $600^{\circ} \mathrm{C}$ or $1000^{\circ} \mathrm{C}$ to obtain the samples group $\mathrm{T} 1 \mathrm{ABC}$ or group $\mathrm{T} 2 \mathrm{ABC}$ (see Table 1 for sample abbreviations), respectively. We used five different heating rates $\left(5^{\circ} \mathrm{C} \mathrm{min}^{-1}, 10^{\circ} \mathrm{C} \mathrm{min}^{-1}\right.$, $20^{\circ} \mathrm{C} \mathrm{min}^{-1}, 50^{\circ} \mathrm{C} \mathrm{min}^{-1}$ and $100^{\circ} \mathrm{C} \mathrm{min}^{-1}$ ) for the samples for both end temperatures. The baseline measured with an empty alumina crucible was subtracted for all the measurements. In order to achieve reproducibility of the results, a small particle size, which is limited by a high content of fat components and a sufficiently high initial mass of the sample, was required, as reported elsewhere. ${ }^{6}$ To evaluate the repeatability, three replications of each thermal process, under the same conditions, were performed. The one-way analysis of variance (ANOVA) was used to determine the statistically significant differences between the samples.

To determine the ash content in the MBM and T1ABC samples the TGA method, analogous to DIN 51719, was used. ${ }^{14}$ Approximately $5 \mathrm{mg}$ of sample in a
$150 \mu \mathrm{L}$ alumina crucible was measured in the TGA/DSC1 Mettler Toledo $(\mathrm{CH})$ thermoanalyser using the following multi-segment thermal program: (1) heating with a rate of $5{ }^{\circ} \mathrm{C} \mathrm{min}-1$ to $106{ }^{\circ} \mathrm{C}$ in a nitrogen atmosphere $(99.999 \%$

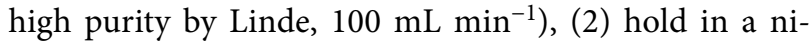
trogen atmosphere at $106{ }^{\circ} \mathrm{C}$ for $30 \mathrm{~min}\left(100 \mathrm{~mL} \mathrm{~min}^{-1}\right)$, (3) temperature increase with a $5{ }^{\circ} \mathrm{C} \mathrm{min}{ }^{-1}$ heating rate to $550{ }^{\circ} \mathrm{C}$ in an oxygen atmosphere $(99.999 \%$ high purity by Linde, $100 \mathrm{~mL} \mathrm{~min}^{-1}$ ), and (4) hold in an oxygen atmosphere at $550{ }^{\circ} \mathrm{C}$ for $60 \mathrm{~min}\left(100 \mathrm{~mL} \mathrm{~min}{ }^{-1}\right)$. The hygroscopic moisture content and the ash content were calculated from the mass loss up to the end of the second step and from the mass loss up to the end of the fourth step of the program run, respectively. The baseline measured with an empty alumina crucible was subtracted for all the measurements. For the evolved gases determination, the thermoanalyser was coupled to a Balzers Thermostar Mass Spectrometer $\left(2.4 \cdot 10^{-6}\right.$ mbar vacuum) via a $75 \mathrm{~cm}$ long capillary heated at $190{ }^{\circ} \mathrm{C}$. The initial sample mass was $2.9 \mathrm{mg}$.

The semi-total concentrations of the elements in the MBM and T1H005 (bulk sample of replicates) were determined after aqua regia digestion. To an amount of $0.200 \mathrm{~g} \pm 0.005 \mathrm{~g}$ of the sample in a PFA digestion vessel (561B, Savillex, Minnesota, USA) $3 \mathrm{~mL}$ of $\mathrm{HNO}_{3}(\geq 69.0 \%$, TraceSelect, Fluka) and $9 \mathrm{~mL}$ of $\mathrm{HCl}(37 \%$, TraceSelect, Fluka, Sigma-Aldrich Chemie) were added, left in the loosely closed vessel in a fume hood overnight, then the vessel was tightly closed and the sample was digested at a temperature of reflux on a hot plate for 8 hours. The cold contents were filtered through a $0.45 \mu \mathrm{m}$ membrane filter and diluted to $30 \mathrm{~mL}$ with Milli-Q water. The samples were digested in triplicate, including three blank samples. The concentration of metals in the digested diluted samples was analysed with ICP-MS Agilent 7500ce ( $\mathrm{Cr}, \mathrm{Ni}, \mathrm{Cu}, \mathrm{Zn}$, $\mathrm{As}, \mathrm{Mo}, \mathrm{Cd}$ and $\mathrm{Pb}$ ) and Varian $240 \mathrm{AA}$ system ( $\mathrm{Fe}, \mathrm{Na}$, $\mathrm{K}, \mathrm{Ca}$ and $\mathrm{Mg}$ ). The limit of detection (LOD) was calculated as the concentration corresponding to three times the standard deviation ( $3 s, N=3$ ) of the blank determinations. Total $\mathrm{P}$ content in digested diluted samples were determined according to SIST EN ISO 6878:2004 (Water quality - Determination of phosphorus - Ammonium molybdate spectrometric method).

The content of $\mathrm{C}, \mathrm{H}, \mathrm{N}$ and $\mathrm{S}$ in the raw MBM sample and the $\mathrm{ABC}$ samples obtained after the pyrolysis of the MBM sample up to $600{ }^{\circ} \mathrm{C}$ (T1ABC samples) was determined with a Perkin Elmer Elemental Analyser Series II $\mathrm{CHNS/O}$. The inorganic carbon content was determined according to DIN 51726. ${ }^{14}$ The organic carbon content $\left(\mathrm{C}_{\text {org }}\right)$ in the samples was derived from the total carbon content minus the inorganic carbon content.

A Perkin Elmer Spectrum 100 spectrometer was used for the FTIR spectroscopy of the MBM and ABC samples. The analyses of the samples were performed with a single reflection monolithic diamond ATR (Specac's Golden Gate ATR) in the wavenumber range from $600 \mathrm{~cm}^{-1}$ to 
$4000 \mathrm{~cm}^{-1}$ (background correction, resolution $2 \mathrm{~cm}^{-1}, 10$ scans for each spectrum).

The mineralogical properties of the $\mathrm{ABC}$ samples were examined with a PANalytical X'Pert PRO MPD powder diffractometer using $\mathrm{Cu} \mathrm{Ka} \mathrm{X-rays} \mathrm{(wavelength} \mathrm{of}$ $1.5406 \AA$ ). The measurements were made in the $2 \theta$ range $5-80^{\circ}$ with a step interval of $0.033^{\circ}$. The results were evaluated with the Crystallographica Search-Match program.

SEM/EDS analyses of ground ABC samples on adhesive carbon tape were used to investigate the morphology and elemental composition of the samples. The Zeiss ULTRA Plus field emission scanning electron microscope was equipped with an energy dispersive spectrometer (EDS Oxford X-Max SDD $50 \mathrm{~mm}^{2} 106$ detector) and INCA 4.14 $\mathrm{X}$-ray microanalysis software. Before analysis, the samples were coated with $\mathrm{Au} / \mathrm{Pd}$ (80:20). SEM images were taken at an acceleration voltage of $5 \mathrm{kV}$ and a working distance of $5.5 \mathrm{~mm}$ with the SE detector, while the elemental analysis of the particles was performed by EDS at $20 \mathrm{kV}$.

\section{Results and Discussion}

\section{1. Pyrolysis of Meat and Bone Meal}

The dynamic TGA measurements of the MBM pyrolysed up to $600{ }^{\circ} \mathrm{C}$ and $1000{ }^{\circ} \mathrm{C}$ show (Figure 1) a similar course for the samples heated at all the heating rates for the observed time period. The mass loss of the samples pyrolysed up to $600{ }^{\circ} \mathrm{C}$ varied between $57.6 \%$ and $59.7 \%$ (Figure 1a, Table 1) with relative standard deviations of the replicates being between $0.76 \%$ and $1.75 \%$. Although there are statistically significant differences $(p<0.05)$ in the mass losses of the samples with different heating rates, a weak correlation between the heating rates and the mass losses was observed. An additional step can be observed in the curves heated up to $1000{ }^{\circ} \mathrm{C}$ (Figure 1b), resulting in a total mass loss of at most $71.4 \%$ and $71.5 \%$ for the heating rates of $5{ }^{\circ} \mathrm{C} \mathrm{min}^{-1}$ and $10{ }^{\circ} \mathrm{C} \mathrm{min}^{-1}$, respectively. With the increased heating rate, the mass loss of the sample diminishes, so that at a heating rate of $100{ }^{\circ} \mathrm{C} \mathrm{min}^{-1}$ it is only $66.6 \%$ (Table 1). We can conclude that at higher heating rates there was not enough time for some of the thermal processes to be completed and therefore certain components were not released from the system.

The same curves on a common temperature scale (Figure 2) indicate that the first step, i.e., dehydration, occurs up to $150^{\circ} \mathrm{C}$ and is relatively small and similar for all the heating rates $(2-4 \%)$. The main mass loss after that temperature, for the curve with the lowest heating rate, can be distinguished in a few related steps. The weight loss up to $210{ }^{\circ} \mathrm{C}(1.6 \%)$ is attributed to the evaporation of low-molecular-weight compounds and the decomposition reactions. The major event occurs in the temperature interval $210-450{ }^{\circ} \mathrm{C}$ and is due to the degradation reactions of the organic intermediates. ${ }^{25} \mathrm{~A}$ shoulder at $340-350{ }^{\circ} \mathrm{C}$ (Figure 1a, DTG curve-embedded graph) probably corre-
Table 1. Sample abbreviations and comparison of the results of the dynamic pyrolysis measurements up to $600{ }^{\circ} \mathrm{C}$ and up to $1000^{\circ} \mathrm{C}$.

\begin{tabular}{lccccc}
\hline Sample & $\begin{array}{c}\mathbf{T} \\
\text { interval } \\
/{ }^{\circ} \mathbf{C}\end{array}$ & $\begin{array}{c}\text { Heating } \\
\text { rate } \\
/{ }^{\circ} \mathbf{C}{\text { } \mathbf{m i n}^{-1}}^{-1}\end{array}$ & $\begin{array}{c}\text { Group } \\
\text { name }\end{array}$ & $\begin{array}{c}\text { Total } \\
\text { mass } \\
\text { loss } / \%\end{array}$ & $\begin{array}{c}\text { Inflection } \\
\text { point } \\
/{ }^{\circ} \mathbf{C}\end{array}$ \\
\hline T1H005 & $25-600$ & 5 & T1ABC & 59.5 & 309.4 \\
T1H010 & & 10 & & 57.7 & 320.2 \\
T1H020 & & 20 & & 57.6 & 335.1 \\
T1H050 & & 50 & & 58.4 & 351.1 \\
T1H100 & & 100 & & 59.7 & 361.2 \\
\hline T2H005 & $25-1000$ & 5 & T2ABC & 71.4 & 308.4 \\
T2H010 & & 10 & & 71.5 & 323.1 \\
T2H020 & & 20 & & 68.6 & 338.0 \\
T2H050 & & 50 & & 68.1 & 352.3 \\
T2H100 & & 100 & & 66.6 & 365.2 \\
\hline
\end{tabular}
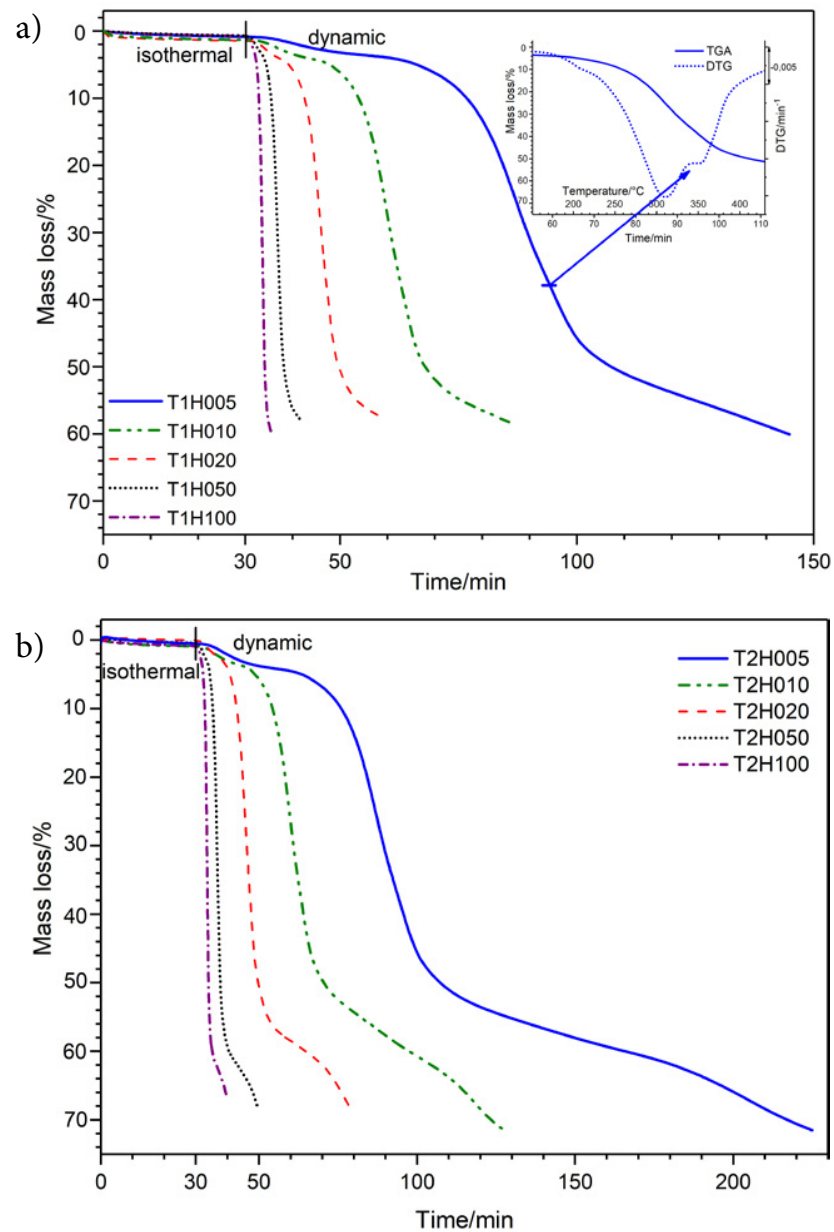

Figure 1. Dynamic TGA curves of the MBM pyrolysed up to $600{ }^{\circ} \mathrm{C}$ (a) and pyrolysed up to $1000{ }^{\circ} \mathrm{C}$ (b) measured with five different

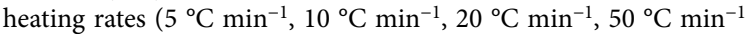
and $\left.100^{\circ} \mathrm{C} \mathrm{min}^{-1}\right)$.

sponds to the start of the degradation of the bones ${ }^{2,4}$. The latter processes overlap at higher heating rates. In the last part of the decomposition, which takes place from $600{ }^{\circ} \mathrm{C}$ to $1000^{\circ} \mathrm{C}$, additional mass losses can be attributed to the 


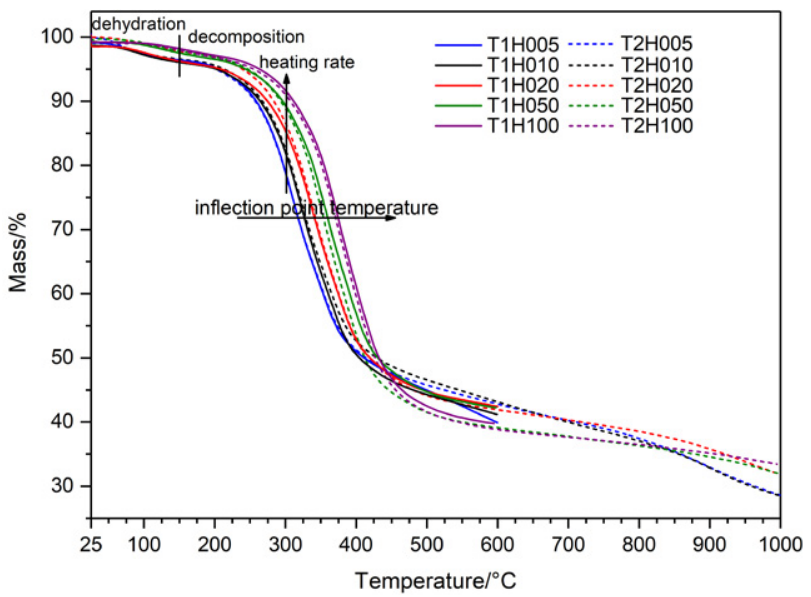

Figure 2. Inflection point determination for the dynamic pyrolysis curves up to $600^{\circ} \mathrm{C}$ and up to $1000^{\circ} \mathrm{C}$ at all heating rates $\left(5^{\circ} \mathrm{C} \mathrm{min}{ }^{-1}\right.$, $10^{\circ} \mathrm{C} \min ^{-1}, 20^{\circ} \mathrm{C} \min ^{-1}, 50^{\circ} \mathrm{C} \min ^{-1}$ and $\left.100{ }^{\circ} \mathrm{C} \min ^{-1}\right)$.

decomposition of the carbonates and other mineral components.

All the curves (in Figure 2), regardless of the final temperature, show a shift in the temperatures of the maximum rate of decomposition (inflection point) which expand between $309.4{ }^{\circ} \mathrm{C}$ and $361.2^{\circ} \mathrm{C}$ for the samples heated up to $600{ }^{\circ} \mathrm{C}$ and between $308.4{ }^{\circ} \mathrm{C}$ and $365.2^{\circ} \mathrm{C}$ for the samples heated up to $1000{ }^{\circ} \mathrm{C}$ to higher temperatures at even temperature intervals with the increasing heating rate (Table 1). These temperatures are in accordance with the data given by other authors for a heating rate of $10{ }^{\circ} \mathrm{C} \mathrm{min}-1$, for example, $310^{\circ} \mathrm{C}$ by Chaala and Roy ${ }^{3}, 335^{\circ} \mathrm{C}$ by Conesa et al. ${ }^{4}$, and $346^{\circ} \mathrm{C}$ by Ayllón et al. ${ }^{6}$ The inflection points occur in the range $72.3-74.6 \%$ of the sample mass, as indicated by the position of the arrow on the graph. The appearance of an inflection point in the first part of the MBM decomposition indicates that a decomposition process above $600^{\circ} \mathrm{C}$ seen on the curves measured up to $1000^{\circ} \mathrm{C}$, is slower and gradual.

\section{2. Determination of the Ash Content in MBM and T1ABC Samples}

The results of TGA determination of the ash content in the MBM and T1ABC samples are presented in Figure 3. For all the curves a similar course with several distinctive step losses was observed. The first one, the release of hygroscopic moisture in the temperature range up to $106^{\circ} \mathrm{C}$ in a nitrogen atmosphere, for all the $\mathrm{ABC}$ samples and the MBM is expected to be small and similar, between $2.9 \%$ and $3.8 \%$ (Table S1 in Supplementary Material). In the temperature range between $106^{\circ} \mathrm{C}$ and $550{ }^{\circ} \mathrm{C}$ in an oxygen atmosphere the major contributions to the weight loss of the samples appear; these are associated with the two-step exothermic decomposition of the organic matter as can be seen for the DSC curve of sample T1H100 in Figure 4, associated with the formation and later decomposition of the intermediate fractions, which only occur in the presence of oxygen. ${ }^{4}$ The remainder of the isothermal part at $550{ }^{\circ} \mathrm{C}$ is the amount of ash in the sample. The results show that the ash quantity in the T1ABC samples increases with the heating rate of the MBM pyrolysis: from $57.4 \%$ at $5{ }^{\circ} \mathrm{C} \mathrm{min}^{-1}$ to $66.6 \%$ at the highest heating rate.

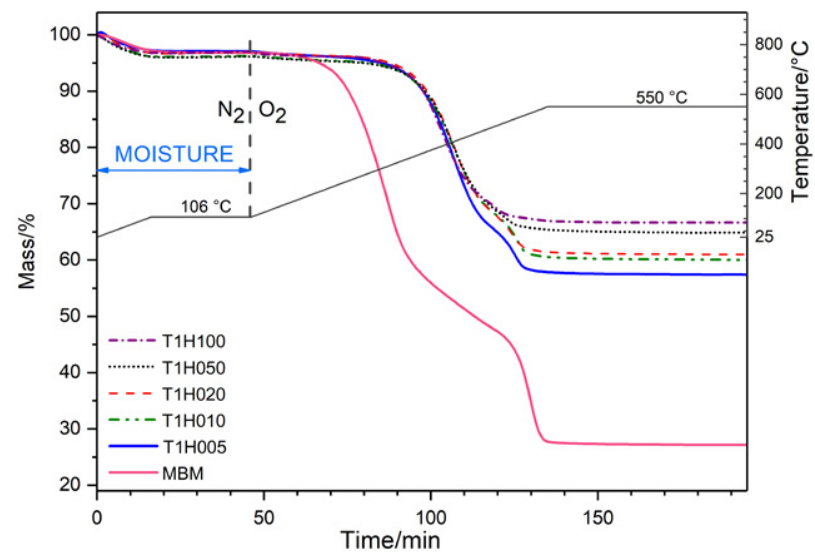

Figure 3. Ash-content determination for T1ABC curves at all five heating rates and MBM sample up to $550^{\circ} \mathrm{C}$.

Figure 4 shows the result curves for the simultaneous TGA-DSC-MS analysis as a sample case, which was performed on the pyrolytic residue of the T1H100 sample using the ash-content determination method. The monotonic decline in the signal $\mathrm{m} / z 18$ and $\mathrm{m} / z$ 44 for the ambient moisture (beside the hygroscopic moisture on the sample) and the carbon dioxide captured in the oven when opening, appears in the nitrogen segments. Switching to the oxygen atmosphere at $106^{\circ} \mathrm{C}$, gives rise to the $\mathrm{CO}_{2}$ gas with accompanying two consecutive exothermic peaks seen on DSC curve, which could be due to the combustion of light aliphatic hydrocarbons $\mathrm{C}_{4} \mathrm{H}_{4}, \mathrm{C}_{2} \mathrm{H}_{6}(\mathrm{~m} / z 52$ and $\mathrm{m} / \mathrm{z} 30)$

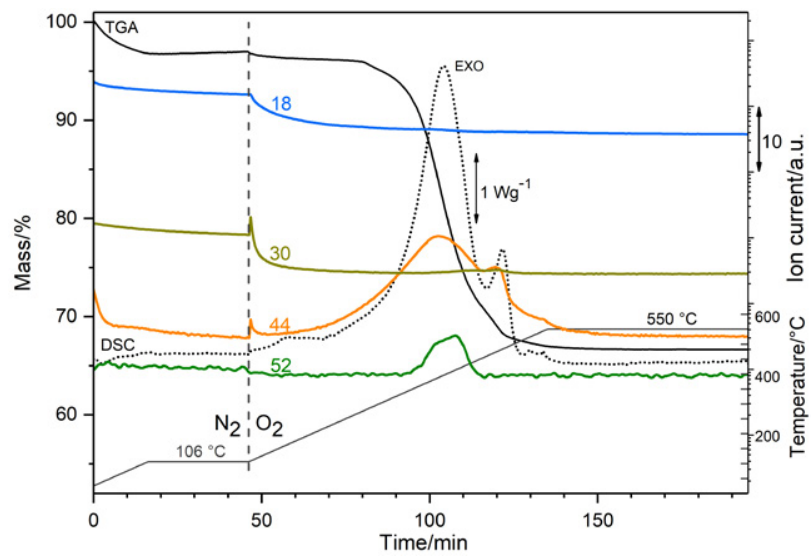

Figure 4. Simultaneous TGA-DSC-MS analysis of the residue of the $\mathrm{T} 1 \mathrm{H} 100$ sample up to $550{ }^{\circ} \mathrm{C}$. 
and in particular to the burned organic residue after the pyrolysis (char), in accordance with database of National Institute of Standards and Technology (NIST).

\section{3. Elemental Analyses of MBM and ABC Samples}

To evaluate the potential hazard posed by PTE in the MBM sample the semi-total concentrations of $\mathrm{Cr}, \mathrm{Ni}, \mathrm{Cu}$, $\mathrm{Zn}, \mathrm{As}, \mathrm{Mo}, \mathrm{Cd}$ and $\mathrm{Pb}$ were determined in the $\mathrm{MBM}$ and T1H005 sample and to evaluate the mineral-part composition of the samples also the concentrations of some macro elements. The elements contained in the original biomass, except elements that are volatile at the pyrolysis temperature, remain in the final products and are therefore more concentrated. The results (see Table S2 in Supplementary Material) showed that the concentrations of PTE in the MBM and T1H005 samples are very low, confirming the low potential environmental risk of both samples according to the PTE content. The concentrations of the PTE elements in both samples are far below the thresholds recommended by the EBC for biochar intended for agricultural use. $^{14}$

The results of the CHNS analyses of the MBM and $A B C$ samples, obtained after the pyrolysis of MBM up to $600{ }^{\circ} \mathrm{C}$ (T1 ABC samples), are presented in Table 2. As a result of the heat treatment of the MBM, the mass content of the $\mathrm{C}, \mathrm{H}, \mathrm{N}$ and $\mathrm{S}$ in the residues decreased. The $\mathrm{C}, \mathrm{H}$, $\mathrm{N}$ and $\mathrm{S}$ contents in the MBM sample are comparable with the literature data, where broad concentration intervals are reported for these elements. ${ }^{2}$ This important variation in MBM composition strongly influences the thermochemical treatment of MBM.

Pyrolysed organic matter with a carbon content lower than $50 \%$ is classified as pyrogenic carbonaceous material. $^{14}$ The presence of $\mathrm{C}$ in the pyrolytic residues is the result of small organic remains, carbonized in argon, and the present of inorganic carbonate groups $\left(\mathrm{CO}_{3}{ }^{2-}\right)$, while $\mathrm{H}$, $\mathrm{N}$ and $\mathrm{S}$ are found predominantly incorporated within the aromatic rings as hetero-atoms and thought to be a major contribution to the highly heterogeneous surface chemistry and reactivity of biochar. ${ }^{26}$ The content of sulphur in all the T1ABC samples (Table 2) is below the detection limit, while the concentrations of $\mathrm{C}, \mathrm{H}$ and $\mathrm{N}$ decreased with increasing heating rate. The results are in accordance with the findings of previous studies, which showed that with increasing pyrolysis rate of biomass the yield of solid char decreases while the yields of gas and liquid phase increases. ${ }^{7,27}$ A lower heating rate allows most of the decomposed organic part of the MBM to be carbonized and thus remain in the solid residue, resulting in a higher carbon content in the samples prepared at a lower heating rate. At higher heating rates, the organic part of the MBM meal decomposes to a lesser extent, but the greater part of the decomposed organic matter is converted to the gas and liquid phase as it is carbonized and remains in the solid residue.

The molar ratios $\mathrm{H} / \mathrm{C}_{\text {org }}$ and $\mathrm{N} / \mathrm{C}_{\text {org }}$ are carbonization degree parameters that characterize the degree of aromaticity of the biochar samples. ${ }^{14} \mathrm{The} \mathrm{H} / \mathrm{C}_{\text {org }}$ as well as the $\mathrm{N} / \mathrm{C}_{\text {org }}$ molar ratios in the T1ABC samples are comparable (on average $0.53 \pm 0.04$ and $0.162 \pm 0.004$, respectively) and represent nearly $30 \%$ and $78 \%$ of the $\mathrm{H} / \mathrm{C}_{\text {org }}$ and $\mathrm{N} /$ $\mathrm{C}_{\text {org }}$ molar ratios of the MBM samples (Table 2). The results indicate a greater loss of $\mathrm{H}$-related than N-related functional groups during the heat treatment of MBM up to $600{ }^{\circ} \mathrm{C}$.

Although there are few studies on the characteristics of $\mathrm{ABC}$ obtained by pyrolysis of bone meal, the literature on the composition and characteristics of MBM pyrolysis products is sparse. Ayllón et al. ${ }^{7}$ investigated the influence of temperature (between $300{ }^{\circ} \mathrm{C}$ and $900{ }^{\circ} \mathrm{C}$ ) and heating rate (from $2{ }^{\circ} \mathrm{C}$ to $14{ }^{\circ} \mathrm{C}$ ) on the fixed bed pyrolysis of MBM. The MBM used in their study had a much higher organic matter content (higher content of CHNS) and consequently an almost $10 \%$ lower ash content than MBM used in our study, making the composition and properties of char samples prepared under conditions similar to those used in our study difficult to compare.

Table 2. Results of CHNS analyses of MBM and T1ABC samples and calculated quantities and ratios.

\begin{tabular}{|c|c|c|c|c|c|c|c|}
\hline Sample & $\begin{array}{c}w(\mathrm{C}) \\
/ \%\end{array}$ & $\begin{array}{c}w(\mathrm{H}) \\
/ \%\end{array}$ & $\begin{array}{c}w(\mathrm{~N}) \\
/ \%\end{array}$ & $\begin{array}{l}w(S) \\
/ \%\end{array}$ & $\begin{array}{c}w\left(\mathrm{C}_{\text {org }}\right) \\
\quad / \%\end{array}$ & $\begin{array}{c}n(\mathrm{H}) \\
\ln \left(\mathrm{C}_{\text {org }}\right)\end{array}$ & $\begin{array}{c}n(\mathrm{~N}) \\
\ln \left(\mathrm{C}_{\text {org }}\right)\end{array}$ \\
\hline MBM & 38.23 & 5.52 & 9.16 & 0.62 & 37.71 & 1.74 & 0.21 \\
\hline T1H005 & 29.95 & 1.27 & 5.55 & $<0.1$ & 28.40 & 0.53 & 0.17 \\
\hline T1H010 & 29.28 & 1.16 & 5.30 & $<0.1$ & 27.80 & 0.50 & 0.16 \\
\hline T1H020 & 28.34 & 1.12 & 5.12 & $<0.1$ & 26.95 & 0.49 & 0.16 \\
\hline T1H050 & 22.38 & 1.06 & 3.83 & $<0.1$ & 20.97 & 0.53 & 0.16 \\
\hline T1H100 & 21.08 & 0.86 & 3.66 & $<0.1$ & 19.54 & 0.60 & 0.16 \\
\hline
\end{tabular}

\section{4. FTIR Spectroscopy}

FTIR spectroscopy was used to compare the presence of functional groups in the untreated MBM sample and the residues after pyrolysis of the MBM sample. The FTIR spectra of the original MBM sample and the commercially available hydroxyapatite (Merck, p.a.) are shown in Figure 5. The broad bands at $3671 \mathrm{~cm}^{-1}$ and $3281 \mathrm{~cm}^{-1}$ in the vibrations-rich FTIR spectrum of the MBM are attributed to the stretching vibrations of the $\mathrm{O}-\mathrm{H}$ bond. The peak near $3700 \mathrm{~cm}^{-1}$ corresponded to vibrations of the $\mathrm{OH}$ groups in inorganic components of the MBM sample, while the $\mathrm{O}-\mathrm{H}$ vibrations of the organic matter appeared at approximately $3000-3300 \mathrm{~cm}^{-1} .^{28}$ The sharp bands at $2919 \mathrm{~cm}^{-1}$ and $2851 \mathrm{~cm}^{-1}$ belong to the asymmetric and symmetric stretching vibrations of the $\mathrm{C}-\mathrm{H}$ bond. In the range from $1750 \mathrm{~cm}^{-1}$ to $1600 \mathrm{~cm}^{-1}$ the $\mathrm{C}=\mathrm{O}$ stretching vibrations of amide (amide I vibra- 
tions) could be assigned, while $\mathrm{C}-\mathrm{N}$ stretching vibrations strongly coupled with $\mathrm{N}-\mathrm{H}$ bending vibrations (amide II) and $\mathrm{N}-\mathrm{H}$ in plane bending vibrations coupled with $\mathrm{C}-\mathrm{N}$ stretching vibrations (amide III) including $\mathrm{C}-\mathrm{H}$ and $\mathrm{N}-\mathrm{H}$ deformation vibrations are found in the range from $1600 \mathrm{~cm}^{-1}$ to $1500 \mathrm{~cm}^{-1}$ and $1350 \mathrm{~cm}^{-1}$ to $1200 \mathrm{~cm}^{-1}$, respectively. ${ }^{29}$ All these bands represent the organic phase of the MBM. ${ }^{23}$ The carbonate asymmetric stretching vibrations typically occur between $1410 \mathrm{~cm}^{-1}$ to $1530 \mathrm{~cm}^{-1} \cdot 21,25,30$ The presence of carbonate in our sample also indicates the observed weak band at $880 \mathrm{~cm}^{-1}$ which could be attributed to the carbonate outof-plane bending vibrations. The bands in the range from $1100 \mathrm{~cm}^{-1}$ to $1000 \mathrm{~cm}^{-1}$ (asymmetric stretching vibrations) and from $600 \mathrm{~cm}^{-1}$ to $500 \mathrm{~cm}^{-1}$ belong to the relatively strong vibrations of the $\mathrm{P}-\mathrm{O}$ bond of the phosphate group. ${ }^{31}$ The most prominent band in the FTIR spectrum of synthetic HA (Figure 5) and the main evidence for the presence of the phosphate group in the compounds is observed at $1026 \mathrm{~cm}^{-1}$. A small band at $892 \mathrm{~cm}^{-1}$ could belong to the vibrations of the $\mathrm{HPO}_{4}{ }^{2-}$ group and indicates the presence of the calcium-deficient apatite $\mathrm{Ca}_{10-\mathrm{x}}(\mathrm{H}-$ $\left.\mathrm{PO}_{4}\right)_{\mathrm{x}}\left(\mathrm{PO}_{4}\right)_{6-\mathrm{x}}(\mathrm{OH})_{2-\mathrm{x}} \cdot{ }^{5,31}$

During the pyrolysis of MBM most of the organic substances decompose and remain in $\mathrm{ABC}$ as small carbonized residues or removed as gas products. The FTIR spectra of the residues of the pyrolysed MBM up to $600{ }^{\circ} \mathrm{C}(\mathrm{T} 1 \mathrm{ABC})$ are present in Figure 6a. Weak vibrations of the $\mathrm{O}-\mathrm{H}$ group in the mineral matter are observed near $3670 \mathrm{~cm}^{-1}$. The intense broad band near
$3300 \mathrm{~cm}^{-1}$, observed in the FTIR spectra of the MBM, and which corresponded to the vibrations of the $\mathrm{OH}$ group in the organic matter, disappeared, suggesting that a large amount of free and associated hydroxyl groups and structural hydroxyl groups were decomposed during the MBM pyrolysis up to $600{ }^{\circ} \mathrm{C} .{ }^{28}$ The weak split bands of the asymmetric and symmetric stretching vibrations of the $\mathrm{C}-\mathrm{H}$ bond $\left(2987 \mathrm{~cm}^{-1}\right.$ and $\left.2901 \mathrm{~cm}^{-1}\right)$ were further observed. The group of bands with the maximum at $1407 \mathrm{~cm}^{-1}$ could be attributed to $\mathrm{C}-\mathrm{C}$ stretching vibrations together with the asymmetric stretching vibrations of the $\mathrm{C}-\mathrm{O}$ bond in the carbonate group. ${ }^{21,30}$ The presence of carbonate also indicates the absorption band at about $871 \mathrm{~cm}^{-1}$. The most intense band in the spectra of the $\mathrm{T} 1 \mathrm{ABC}$ samples belongs to the stretching vibrations of the phosphate group where a slow shift of the band maxima from $1067 \mathrm{~cm}^{-1}$ at sample T1H100 to $1026 \mathrm{~cm}^{-1}$ at sample T1H005 was observed.

The main phosphate-group vibration bands in the FTIR spectra of MBM pyrolysis residues during the thermal treatment up to $1000{ }^{\circ} \mathrm{C}$ (Figure $6 \mathrm{~b}$ ) are found at $1026 \mathrm{~cm}^{-1}$ for all the T2ABC samples. Small band shoulders near $957 \mathrm{~cm}^{-1}$ and $1100 \mathrm{~cm}^{-1}$ were observed which can be assigned to the $\beta$-tricalcium phosphate phases. ${ }^{30}$ The presence of the $\beta-\mathrm{NaCaPO}_{4}$ phase was also confirmed in XRD spectra of T2ABC samples (see Figure 7), prepared at lower heating rates. At $3670 \mathrm{~cm}^{-1}$ the weak band of stretching vibrations of the inorganic $\mathrm{O}-\mathrm{H}$ group was still visible. We also observed the weak bands of the $\mathrm{C}-\mathrm{H}$ stretching vibrations $\left(2987 \mathrm{~cm}^{-1}\right.$ and $\left.2901 \mathrm{~cm}^{-1}\right)$,

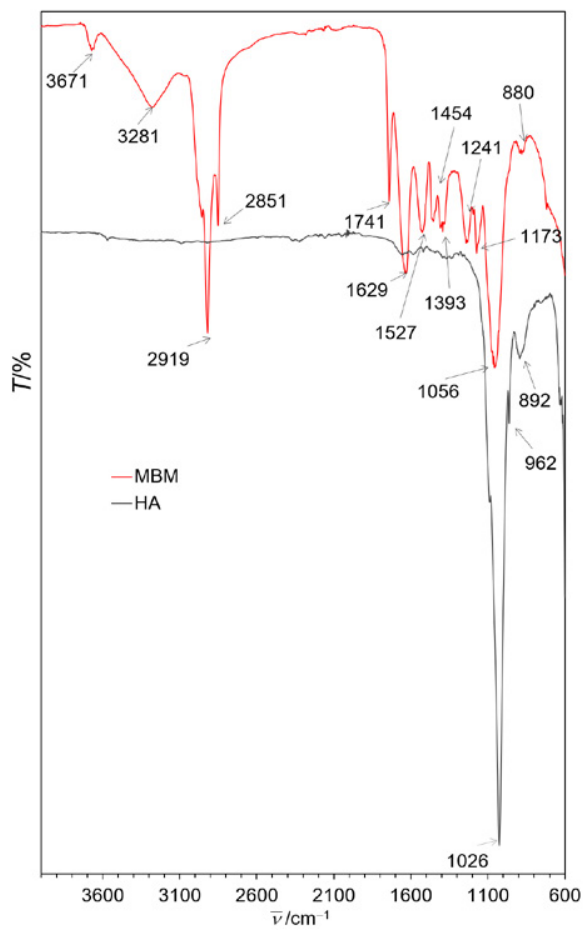

Figure 5. FTIR spectra of untreated MBM sample and commercially available hydroxyapatite.
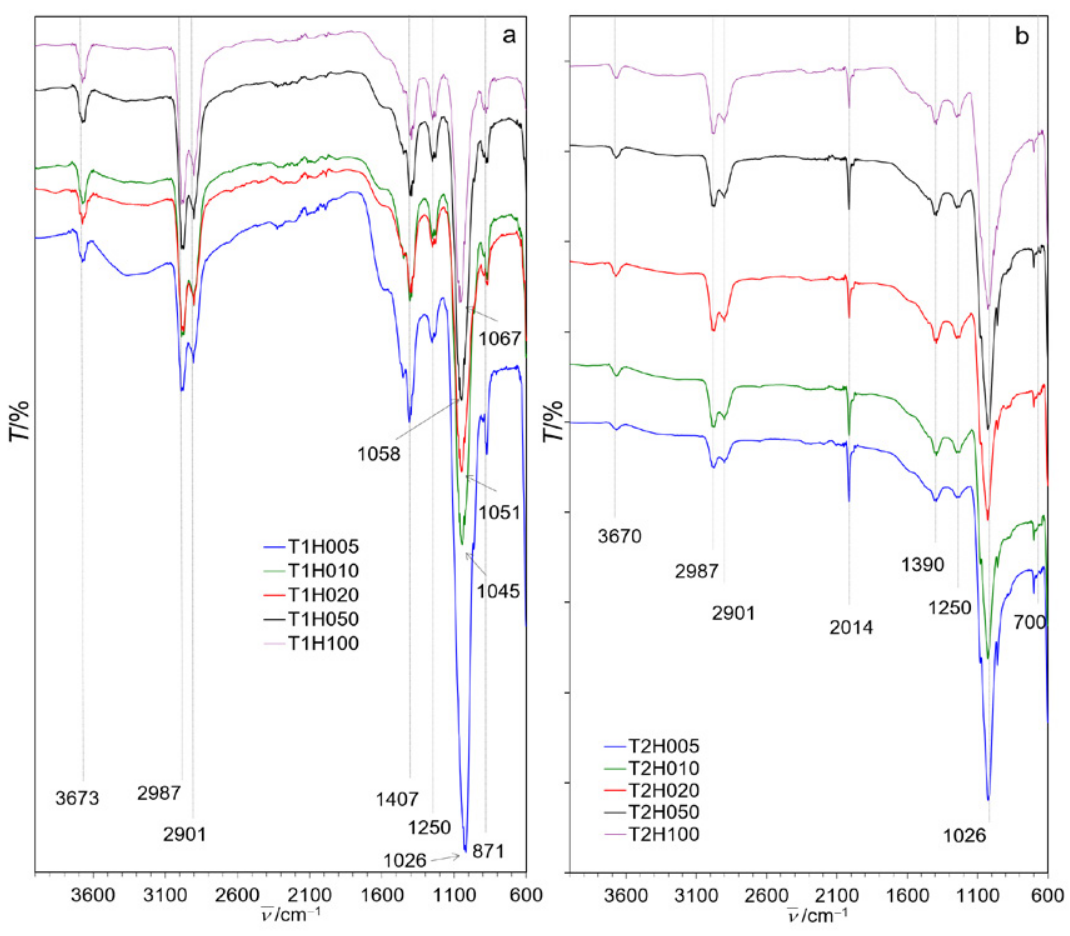

Figure 6. FTIR spectra of residues after MBM pyrolysis up to $600{ }^{\circ} \mathrm{C}$ (a) and up to $1000^{\circ} \mathrm{C}$ (b) at five different heating rates. 
while the carbonate group vibrations $\left(1407 \mathrm{~cm}^{-1}\right.$ and $871 \mathrm{~cm}^{-1}$ ) disappeared. In all T2ABC samples, a new sharp band of unknown origin is observed at $2014 \mathrm{~cm}^{-1}$, which is also observed in FTIR spectra of animal bones pyrolysed at $450{ }^{\circ} \mathrm{C}$ and higher ${ }^{22}$ and in FTIR spectra of monolithic bone blocks pyrolysed at $800{ }^{\circ} \mathrm{C} .{ }^{21}$ Since the band is not observed in the FTIR spectrum of synthetic hydroxyapatite (see Figure 5), we conclude that it probably belongs to an inorganic form of $\mathrm{C}$ that was trapped in the structure.

\section{5. X-ray Powder Diffraction Analysis}

The results of the X-ray powder-diffraction analyses showed that the peak intensities of all the T1ABC samples, regardless of the heating rate, indicate the presence of poorly crystalline phases (Figure 7). The weak broad peaks with no visible peak splitting observed can be attributed to $\mathrm{Cl}$-bearing hydroxyapatite. A decrease in the peak width and a considerable increase in the peak intensity can be observed for the $\mathrm{ABC}$ prepared for the pyrolysis end temperature of $1000{ }^{\circ} \mathrm{C}$ (T2ABC samples) at lower heating rates. This indicates an increase in the size of the crystals, since crystallinity is a measure of the particle size. ${ }^{26}$ The crystallinity of the samples decreases with the higher heating rates, suggesting that some of the phases present are still not well crystallized. The presence of crystalline Cl-bearing hydroxyapatite $\left(\mathrm{Ca}_{5}\left(\mathrm{PO}_{4}\right)_{3}(-\right.$ $\mathrm{Cl}, \mathrm{OH})$ and $\beta$-sodium calcium phosphate $\left(\mathrm{NaCaPO}_{4}\right)$ was confirmed.

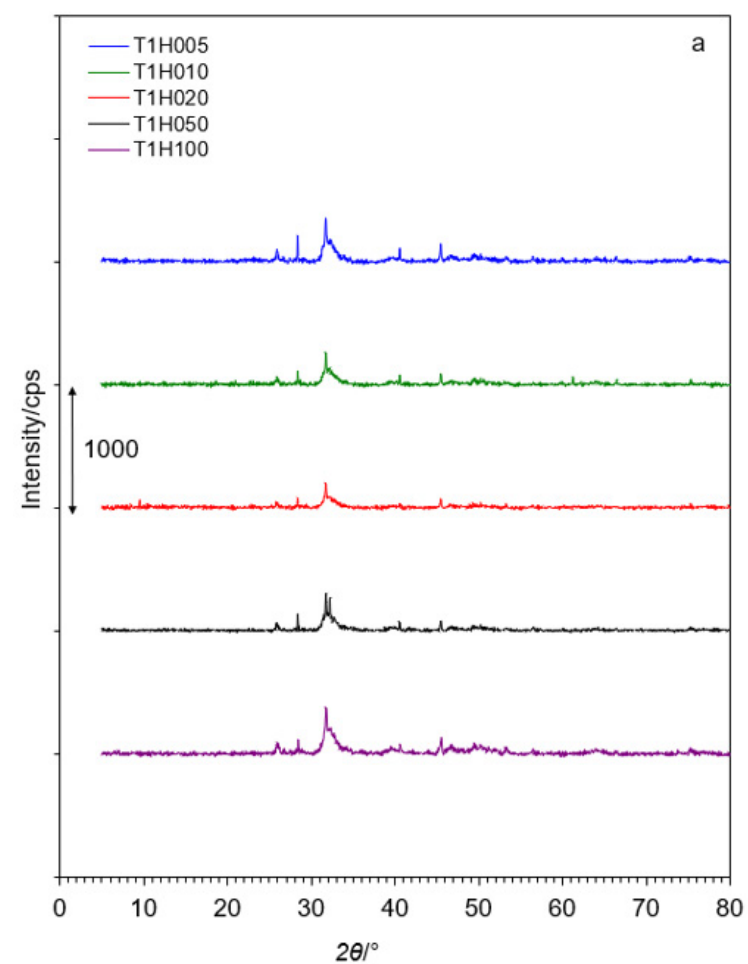

\section{6. SEM/EDS Analysis}

The results of the SEM/EDS analyses revealed the strong influence of both, the pyrolysis end temperature and the heating rate on the morphology and the chemical composition of the final products. Figure 8 presents SEM images of the MBM pyrolysis residues obtained at pyrolysis end temperature $600{ }^{\circ} \mathrm{C}$ (upper row) and $1000{ }^{\circ} \mathrm{C}$ (bottom row) and at heating rates of $5^{\circ} \mathrm{C} \min ^{-1}$ (a and $\mathrm{d}$ ), $20{ }^{\circ} \mathrm{C} \min ^{-1}\left(\mathrm{~b}\right.$ and $\mathrm{e}$ ) and $100{ }^{\circ} \mathrm{C} \mathrm{min}^{-1}(\mathrm{c}$ and $\mathrm{f}$ ).

In the SEM images of the T1ABC samples (Figure 8, upper row) large amorphous agglomerates with varying rough to smooth surface texture were observed. In sample T1H005 the very beginning of small, poorly crystalline particles (up to few $100 \mathrm{~nm}$ ), together with amorphous spilled formations (the EDS analysis shows us that these are amorphous $\mathrm{KCl}$ and $\mathrm{NaCl}$ - see Figure 9) are clearly visible.

The SEM images of the T2ABC samples (Figure 8, bottom row) give us a completely different picture. The difference in particle size is clearly visible. The size of the well-crystallized particles of $\mathrm{T} 1 \mathrm{H} 005$ ranges from less than $0.5 \mu \mathrm{m}$ to several tens of $\mu \mathrm{m}$. Also in the sample T2H020 the particles are already well crystallized, but in contrast to the particles in the sample T2H005 they are much smaller (from less than $1 \mu \mathrm{m}$ up to a few $\mu \mathrm{m}$ ) and stacked together into larger aggregates. The particles in the sample T2H100 exhibit very poor crystallinity. They are located in small aggregates and reach a size of up to $1 \mu \mathrm{m}$.

The distribution of elements over a particular area of the sample can be viewed using EDS elemental mapping. Element maps of the samples T1H005, T2H005, T1H100

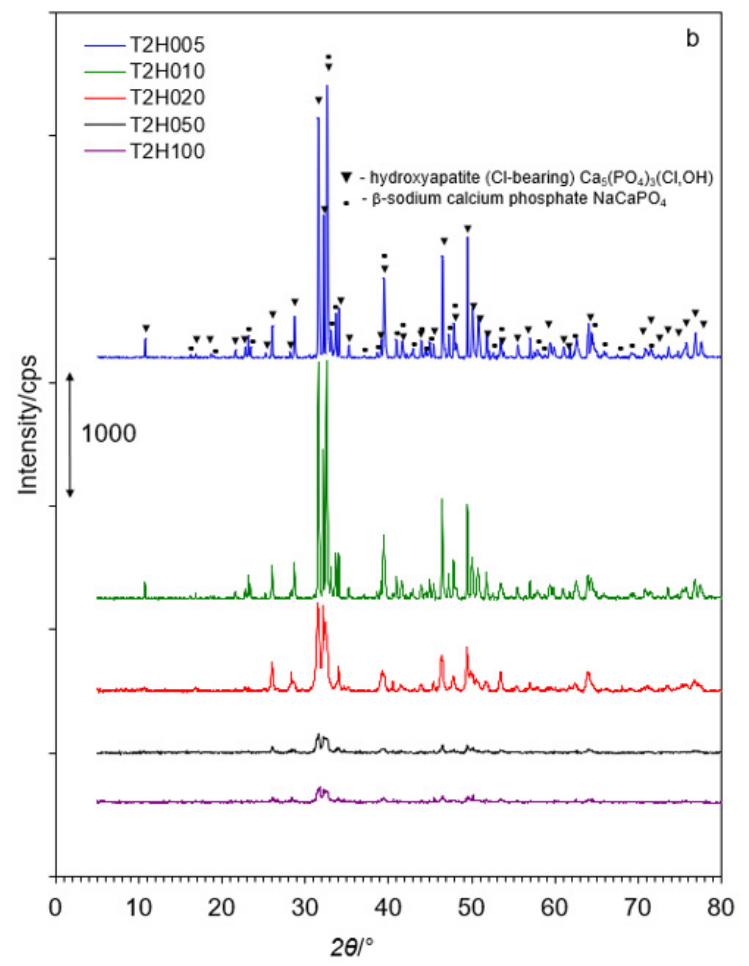

Figure 7. XRD pattern of residues after pyrolytic MBM decomposition up to $600{ }^{\circ} \mathrm{C}$ (left) and $1000{ }^{\circ} \mathrm{C}$ (right) for different heating rates. 

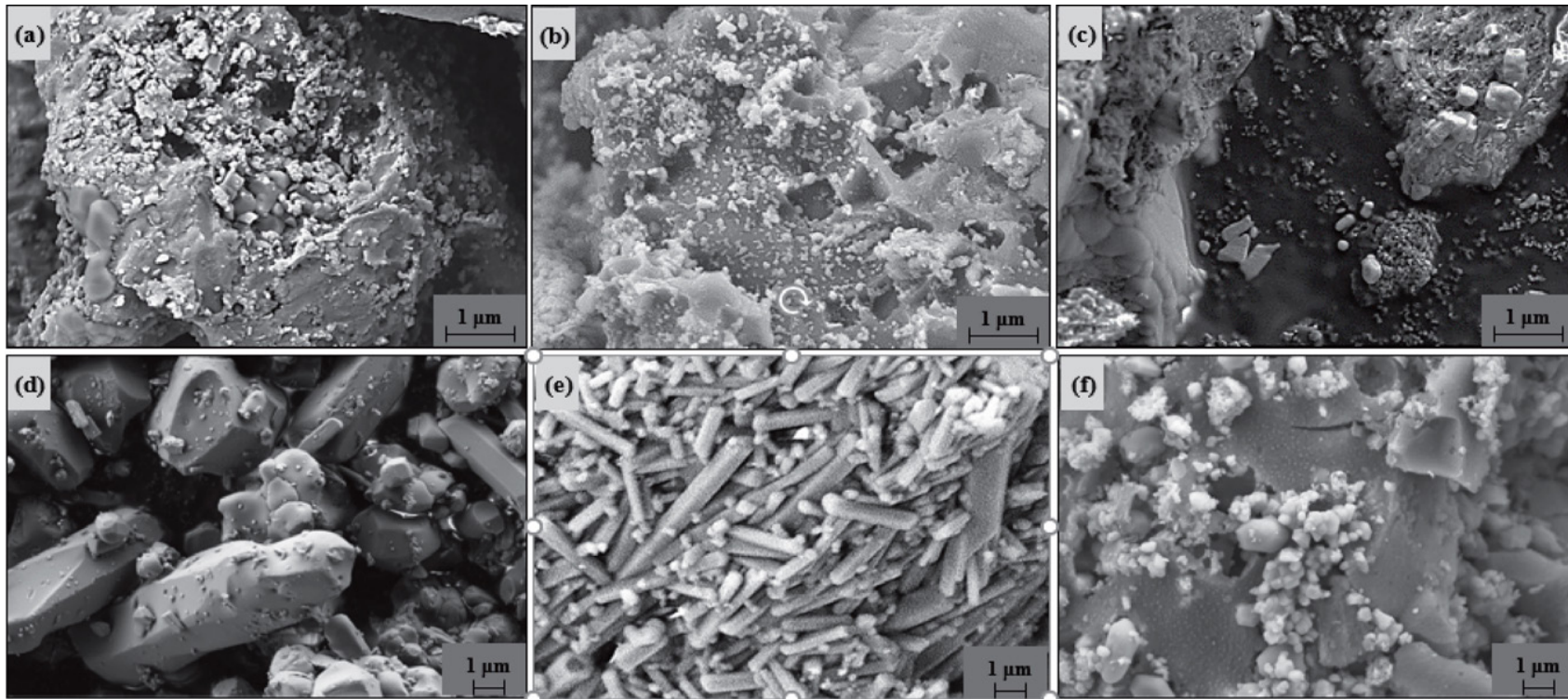

Figure 8. SEM images of T1ABC (upper row) and T2ABC (bottom row) samples at heating rates $5{ }^{\circ} \mathrm{C} \mathrm{min}^{-1}$ (a and $\mathrm{d}$ ), $20^{\circ} \mathrm{C} \mathrm{min}-1$ (b and e) and $100{ }^{\circ} \mathrm{C} \min ^{-1}$ (c and f).
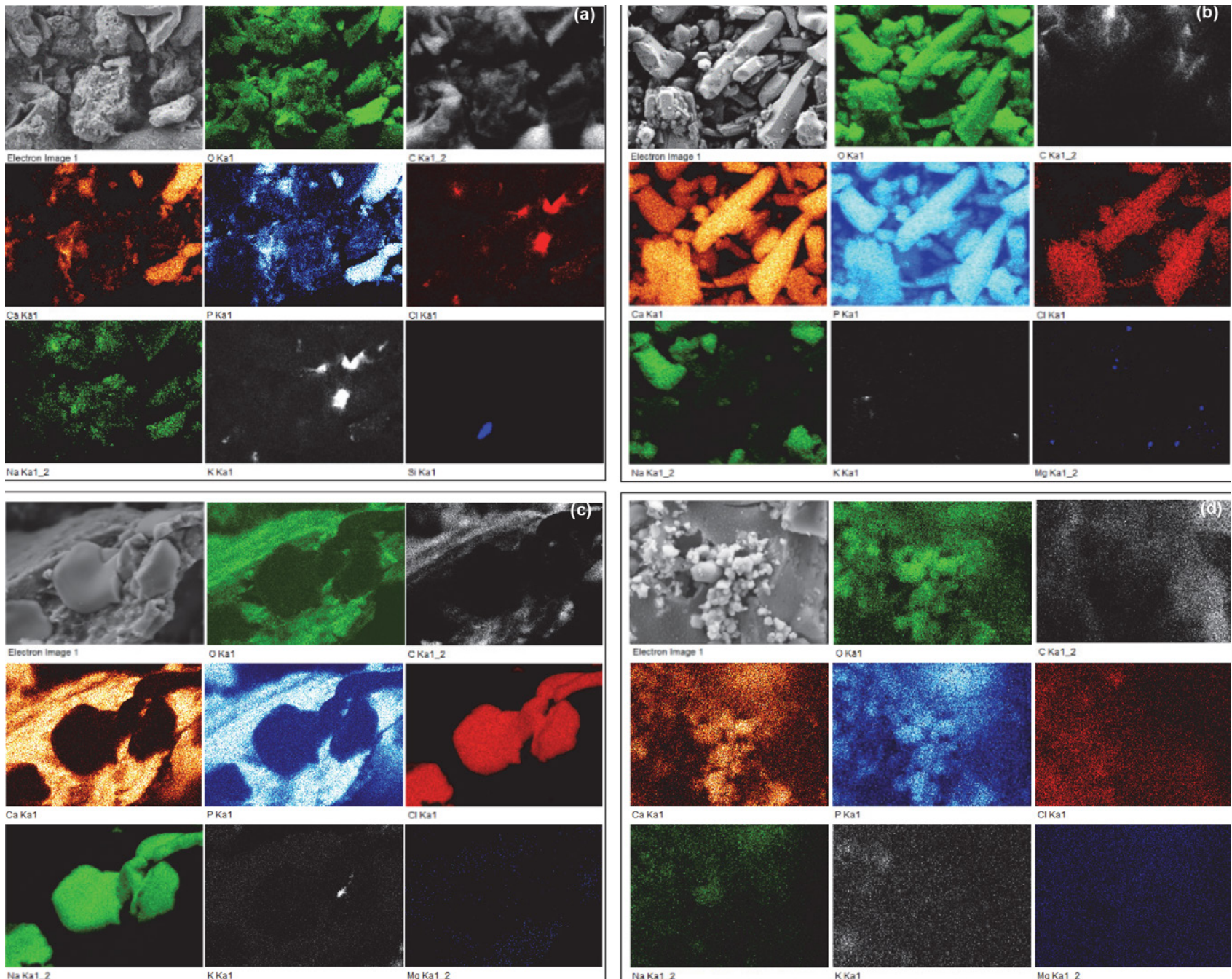

Figure 9. EDS maps of elemental distribution in the samples T1H005 (a), T2H005 (b), T1H100 (c) and T2H100 (d). Distribution of the elements from left to right for all samples: upper line - electron image, oxygen, carbon; in the middle - calcium, phosphorus, chlorine; bottom line - sodium, potassium, magnesium or silicon (sample T1H005). 
and T2H100 are shown in Figure 9. The EDS analyses revealed that carbon (grey images in the top right of the maps (a) and (c)) is still present in samples T1H005 and T1H100. The co-appearance of oxygen (green images in the first line), calcium (orange images) and phosphorus (pale-blue images) is clearly evident for all four samples, indicating the presence of apatite. For sample T1H005 a dispersed distribution of sodium is observed, although it is generally consistent with the distribution of $\mathrm{Ca}$ and $\mathrm{P}$. The presence of $\mathrm{KCl}$ and a small particle containing silicon are also observed. For sample T1H100, sodium is observed in the form of amorphous $\mathrm{NaCl}$, deposited onto the porous surface of the apatite.

Compared to the sample T1H005, where the composition of the apatite particles is relatively uniform, a more diverse composition of apatite is observed in the T2H005 sample. The chlorine-bearing (red image) apatite particles, whose presence was confirmed by XRD analysis, contain the largest amount of calcium. In the apatite particles with a lower calcium content the higher sodium content was observed. The presence of $\beta$-sodium calcium phosphate was also confirmed by XRD analysis. In the sample T2H100 the disperse distribution of the elements is observed, although the co-association of $\mathrm{O}, \mathrm{Ca}$ and $\mathrm{P}$ is clearly visible.

\section{Conclusions}

The results of the MBM pyrolysis study at various final temperatures of pyrolysis and various heating rates revealed the strong influence of both, not only the pyrolysis end temperature, but also the strong influence of the heating rate on the morphology and chemical composition of the final products.

The TGA measurements showed a similar course of pyrolysis for the MBM samples heated at all the heating rates with the major pyrolytic event occurring in the temperature interval $210-450^{\circ} \mathrm{C}$ being due to the degradation reactions of organic intermediates. An additional mass loss up to $12 \%$ above $600{ }^{\circ} \mathrm{C}$ at low heating rates can be attributed to the decomposition of carbonates and other mineral components. Diminishing of the mass loss with increasing heating rate suggest a shortage of time for some thermal processes to be completed. The ash content in the $\mathrm{T} 1 \mathrm{ABC}$ samples was in general increased with the increasing heating rate.

The concentrations of PTE in the MBM are very low, which confirmed that the MBM pyrolytic residues are environmentally acceptable materials. The results of the CHNS analyses of the MBM and T1ABC samples showed that the concentrations of carbon, hydrogen and nitrogen decreased with increasing heating rate and indicated a greater loss of $\mathrm{H}$-related than $\mathrm{N}$-related functional groups. The results of the X-ray powder diffraction analyses showed that the peak intensity of all the residues of the pyrolysis end temperature at $600{ }^{\circ} \mathrm{C}$, regardless of the rate of heating, indicates a low crystallinity, while the crystallinity of the samples obtained for the pyrolysis of the MBM to $1000^{\circ} \mathrm{C}$ is reduced at higher heating rates. The presence of $\mathrm{Cl}$-bearing hydroxyapatite and $\beta$-sodium calcium phosphate was determined. The results of the SEM/EDS analyses revealed the strong influence of the pyrolysis end temperature and the heating rate on the morphology and chemical composition of the final products of the meat and MBM pyrolysis and confirmed the results of the XRD analyses.

Although in practice raw MBM samples differ considerably in organic matter content, which can have a very strong influence on the pyrolysis process itself, our results have clearly shown that both, a pyrolysis end temperature of at least $600{ }^{\circ} \mathrm{C}$ or higher and lower heating rates are required to produce $\mathrm{ABC}$ samples with satisfactory properties.

The results of this study imply the utilization of the pyrolysis residue of industrial by-products such as MBM as one of the attractive approaches that could improve the sustainable use of phosphate-bearing sources.

\section{Acknowledgements}

The authors would like to thank the Slovenian Research Agency (ARRS) for the financial support of the Network of Research Infrastructure Centres of the University of Ljubljana (MRIC UL), on whose equipment the part of the research was carried out, and for the financial support from the research programme P1-0134b: Chemistry for Sustainable Development. Thanks also to the native speaker Dr. Paul John McGuiness for his contribution to the improvement of the English language.

\section{Declaration of conflicting interest}

The authors declare that they have no known competing financial interests or personal relationships that could have appeared to influence the work reported in this paper.

\section{References}

1. N. Vassilev, E. Martos, G. Mendes, V. Martos and M. Vassileva, J. Sci. Food Agric. 2013, 93, 1799-1804.

DOI:10.1002/jsfa.6130

2. E. Cascarosa, G. Gea and J. Arauzo, Renewable Sustainable Energy Rev. 2012, 16, 942-957. DOI:10.1016/j.rser.2011.09.015

3. A. Chaala and C. Roy, Environ. Sci. Technol. 2003, 37, 4517-4522. DOI:10.1021/es026346m

4. J. A. Conesa, A. Fullana and R. Font, J. Anal. Appl. Pyrolysis 2003, 70, 619-630. DOI:10.1016/S0165-2370(03)00044-5

5. E. Deydier, R. Guilet, S. Sarda and P. Sharrock, J. Hazard. Mater. 2005, 121, 141-148. DOI:10.1016/j.jhazmat.2005.02.003

6. M. Ayllón, G. Gea, M. B. Murillo, J. L. Sánchez and J. Arauzo, J. Anal. Appl. Pyrolysis 2005, 74, 445-453.

DOI:10.1016/j.jaap.2004.11.022 
7. M. Ayllón, M. Aznar, J. L. Sánchez, G. Gea and J. Arauzo, Chem. Eng. J. 2006, 121, 85-96. DOI:10.1016/j.cej.2006.04.013

8. M. Coutand, M. Cyr, E. Deydier, R. Guilet and P. Clastres, J. Hazard. Mater. 2008, 150, 522-532.

DOI:10.1016/j.jhazmat.2007.04.133

9. I. Gulyurtlu, D. Boavida, P. Abelha, M. H. Lopes and I. Cabrita, Fuel 2005, 84, 2137-2148. DOI:10.1016/j.fuel.2005.04.024

10.G. Skodras, P. Grammelis, P. Basinas, S. Kaldis, E. Kakaras and G. P. Sakellaropoulos, Fuel Process. Technol. 2007, 88, 787-794. DOI:10.1016/j.fuproc.2007.03.009

11. O. Senneca, Fuel 2008, 87, 3262-3270. DOI:10.1016/j.fuel.2008.04.012

12. E. Cascarosa, L. Gasco, G. García, G. Gea and J. Arauzo, Resour. Conserv. Recycl. 2012, 59, 32-37.

DOI:10.1016/j.resconrec.2011.06.005

13. S. Bhardwaj, M. Sharon and M. Sharon, in: W. S. Donahue, J. C. Brandt (Ed): Pyrolysis: Types, Processes, and Industrial Sources and Products, Nova Science Publishers, UK, 2009, pp. 117-130.

14. EBC, European Biochar Certificate - Guidelines for a sustainable production of biochar. European Biochar Foundation (EBC). Version 8.2E of $19^{\text {th }}$ April 2019).

DOI: $10.13140 /$ RG.2.1.4658.7043

15. M. J. Zwetsloot, J. Lehmann, T. Bauerle, S. Vanek, R. Hestrin and A. Nigussie, Plant Soil 2016, 408, 95-105.

DOI:10.1007/s11104-016-2905-2

16. N. A. Medellin-Castillo, R. Leyva-Ramos, E. Padilla-Ortega, R. O. Perez, J. V. Flores-Cano and M. S. Berber-Mendoza, J. Ind. Eng. Chem. 2014, 20, 4014-4021.

DOI:10.1016/j.jiec.2013.12.105

17. S. B. Chen, Y. G. Zhu, Y. B. Ma and G. McKay, Environ. Pollut. 2006, 139, 433-439. DOI:10.1016/j.envpol.2005.06.007

18. J. C. Moreno-Piraján, R. Gómez-Cruz, V. S. García-Cuello and L. Giraldo, J. Anal. Appl. Pyrolysis 2010, 89, 122-128. DOI:10.1016/j.jaap.2010.06.007
19. M. Morshedizad, D. Zimmer and P. Leinweber, J. Soil Sci. Plant Nutr. 2016, 179, 388-398. DOI:10.1002/jpln.201500604

20. E. Gruden, P. Bukovec and M. Zupančič, Acta Chim. Slov. 2017, 64, 577-581. DOI:10.17344/acsi.2016.2889

21. M. Krzesińska and J. Majewska, J. Anal. Appl. Pyrolysis 2015, 116, 202-214. DOI:10.1016/j.jaap.2015.09.009

22. S. Patel, J. Han, W. Qiu and W. Gao, J. Environ. Chem. Eng. 2015, 3, 2368-2377. DOI:10.1016/j.jece.2015.07.031

23. C. K. Rojas-Mayorga, A. Bonilla-Petriciolet, I. A. Aguayo-Villarreal, V. Hernández-Montoya, M. R. Moreno-Virgen, R. Tovar-Gómez and M. A. Montes-Morán, J. Anal. Appl. Pyrolysis 2013, 104, 10-18. DOI:10.1016/j.jaap.2013.09.018

24. K. Tõnsuaadu, K. A. Gross, L. Plūduma and M. Veiderma, J. Therm. Anal. Calorim. 2012, 110, 647-659.

DOI:10.1007/s10973-011-1877-y

25.B. Charmas, Thermochim. Acta 2013, 573, 73-81. DOI:10.1016/j.tca.2013.08.032

26. J. Bourke, M. Manley-Harris, C. Fushimi, K. Dowaki, T. Nunoura and M. J. Antal, Ind. Eng. Chem. Res. 2007, 46, 5954-5967. DOI:10.1021/ie070415u

27. P. T. Williams and S. Besler, Renew. Energy 1996, 7, 233-250. DOI:10.1016/0960-1481(96)00006-7

28. J. Jin, Y. Li, J. Zhang, S. Wu, Y. Cao, P. Liang, J. Zhang, M. H. Wong, M. Wang, S. Shan and P. Christie, J. Hazard. Mater. 2016, 320, 417-426. DOI:10.1016/j.jhazmat.2016.08.050

29. E. P. Paschalis, R. Mendelsohn and A. L. Boskey, Clin. Orthop. Relat. Res. 2011, 469, 2170-2178.

DOI:10.1016/j.tca.2006.04.013

30. S. Meejoo, W. Maneeprakorn and P. Winotai, Thermochim. Acta 2006, 447, 115-120. DOI:10.1016/j.tca.2006.04.013

31. A. Destainville, E. Champion, D. Bernache-Assollant and E. Laborde, Mater. Chem. Phys. 2003, 80, 269-277.

DOI:10.1016/S0254-0584(02)00466-2

\section{Povzetek}

Izčrpavanje zalog fosfatnih rud kot glavnega vira fosforja je privedlo do iskanja novih, alternativnih in okolju prijaznejših produktov in procesov pridobivanja. Eden izmed varnih in okolju prijaznih fosfatnih virov je oglje iz živalskih kosti (ABC), pridobljeno s pirolizo mesno-kostne moke (MBM). V predstavljeni študiji smo raziskovali vpliv pogojev pirolize MBM na fizikalno-kemijske lastnosti pripravljenih produktov (ABC). Pirolizo MBM smo izvedli pri dveh končnih temperaturah $\left(600^{\circ} \mathrm{C}\right.$ in $\left.1000{ }^{\circ} \mathrm{C}\right)$ in petih različnih hitrosti segrevanja $\left(5^{\circ} \mathrm{C} \mathrm{min}-1,10^{\circ} \mathrm{C} \mathrm{min}{ }^{-1}, 20^{\circ} \mathrm{C} \min ^{-1}, 50{ }^{\circ} \mathrm{C} \mathrm{min}{ }^{-1}\right.$

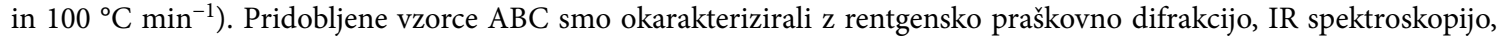
elementno CHNS analizo in SEM/EDS analizo. Rezultati so pokazali močan vpliv tako končne temperature pirolize kot tudi hitrosti segrevanja na morfologijo in kemijsko sestavo pridobljenih produktov.

Except when otherwise noted, articles in this journal are published under the terms and conditions of the Creative Commons Attribution 4.0 International License 